\title{
KRIMINALISASI BERLEBIH (OVERCRIMINALIZATION) DALAM KRIMINALISASI KORUPSI
}

\author{
Marthen H. Toelle \\ Advokat/Praktisi Hukum di Bidang Jasa Konstruksi \\ dan Pengadaan Barang/Jasa Pemerintah \\ Korespondensi: marthentoelle@yahoo.com
}

\begin{abstract}
Abstrak
Artikel ini berargumen bahwa kriminalisasi dalam Pasal 2 ayat (1) dan Pasal 3 UU Tipikor adalah praktik kriminalisasi berlebih. Praktik kriminalisasi berlebih pada hakikatnya adalah keputusan menetapkan suatu tindakan sebagai tindak pidana dalam undang-undang tanpa didukung oleh alasan yang memadai. Dalam kontrak dengan pemerintah, perlindungan terhadap keuangan negara sudah memadai sehingga tindakan merugikan keuangan negara tidak perlu dikriminalisasi atau dipidana berdasarkan Pasal 2 ayat (1) dan Pasal 3 UU Tipikor.
\end{abstract}

Kata-kata Kunci: Kriminalisasi; Kontrak; Korupsi.

\begin{abstract}
This article argues that the criminalization stipulated in Articles 2(1) and 3 of the Indonesian Anti-Corruption Act is overcriminalization. Overcriminalization is, in essence, the decision to criminalize certain behaviour without being supported by adequate reasons. In government contracts, the protection over State budget has been properly established, therefore any State budget loss should not necessarily be criminalized according to Articles 2 (1) and 3 of the Indonesian Anti-Corruption Act.
\end{abstract}

Key words: Criminalization; Contract; Corruption. 


\section{PENDAHULUAN}

Tulisan singkat ini hendak mengkritisi keputusan pembentuk undang-undang (legislator) mengkriminalkan perbuatan yang merugikan keuangan negara sebagai tindak pidana korupsi dalam Pasal 2 ayat (1) dan Pasal 3 Undang-Undang Nomor 31 Tahun 1999 yang diubah dengan Undang-Undang Nomor 20 Tahun 2001 (UU Tipikor). Kriminalisasi tersebut akan dikritisi dengan konsep dalam Teori Hukum Pidana (Criminal Law Theory) yang disebut kriminalisasi berlebih (overcriminalization). Dalam melakukan refleksi kritis penulis bertolak dari pengalaman sebagai praktisi hukum yang menggeluti bidang jasa konstruksi di mana dalam praktik tersebut banyak timbul kasus-kasus tindak pidana korupsi yang bersumber dari pelaksanaan kontrak kerja konstruksi dengan pemerintah.

Berdasarkan pengalaman penulis, pemahaman aparat penegak hukum tentang Pasal 2 ayat (1) dan Pasal 3 UU Tipikor sangat kurang memadai secara teoretis, sehingga ketentuan tersebut berdampak menjadi praktik pengenaan sanksi pidana secara berlebihan karena konstruksi ketentuan hukumnya sangat elastis. Kondisi demikian adalah isu sangat serius dalam Hukum Pidana jika dikaitkan dengan asas-asas dan doktrin Hukum Pidana itu sendiri. Oleh karena itu, dalam konteks tersebut, dikaitkan dengan pengalaman praktik hukum penulis, Pasal 2 ayat (1) dan Pasal 3 UU Tipikor akan dikritik sebagai praktik kriminalisasi berlebih yang bertentangan dengan hakikat dari Hukum Pidana. Kritik tersebut tentu saja dilihat dari isu yang spesifik yaitu penjatuhan sanksi pidana terhadap pelaksanaan kontrak kerja konstruksi dengan pemerintah yang dikualifikasi merugikan keuangan negara berdasarkan Pasal 2 ayat (1) dan Pasal 3 UU Tipikor.

Untuk sampai pada argumen kritik tersebut, pertama-tama penulis akan menjelaskan tentang pembatasan terhadap kekuasaan pembentuk undang-undang dalam melakukan kriminalisasi. Selanjutnya, sebagai implikasinya, dirumuskan konsep kriminalisasi yang legitimate. Berbareng dengan itu, dirumuskan pula konsep kriminalisasi yang tidak legitimate, di mana salah satu bentuknya adalah kriminalisasi berlebih. Terakhir, atas dasar pemikiran tersebut dilakukan telaah kritis terhadap Pasal 2 ayat (1) dan Pasal 3 UU Tipikor dikaitkan dengan penerapannya dalam menjatuhkan sanksi pidana terhadap pelaksanaan kontrak kerja konstruksi dengan pemerintah yang dikualifikasi merugikan keuangan negara. Dari hasil analisis kritis tersebut maka dilakukan penyimpulan bahwa Pasal 2 ayat (1) dan Pasal 3 UU Tipikor adalah bentuk praktik kriminalisasi berlebih oleh pembentuk undang-undang. ${ }^{1}$

Dalam pembahasan ini argumen penulis dibatasi hanya berlaku untuk fase pelaksanaan kontrak. Dengan demikian penulis tidak menutup kemungkinan tindak pidana dalam fase pra-kontrak. Justru inilah isu utama dalam kegiatan pengadaan barang dan jasa pemerintah. Jangan karena kasus yang terjadi di fase pra-kontrak tidak mampu dibuktikan maka kemudian tindak pidananya diarahkan pada fase pelaksanaan kontrak yang lebih mudah dibuktikan tindak pidananya. 


\section{PEMBAHASAN}

\section{Pembatasan terhadap Kekuasaan Kriminalisasi Pembentuk Undang- Undang}

Kriminalisasi menurut Nina Persak adalah "defining certain human conduct (acts or omissions) as criminal offences and usually assign-ing to them a certain range of criminal law sanctions." Berdasarkan Pasal 1 ayat (1) Kitab Undang-undang Hukum Pidana (KUHP) yang lebih dikenal sebagai asas legalitas, suatu tindakan hanya dapat dikualifikasi sebagai tindak pidana manakala negara telah melakukan kriminalisasi terhadap tindakan tersebut melalui undang-undang (legislasi).

Secara prinsip, sesuai pengertian di atas, menentukan suatu tindakan sebagai tindak pidana (kriminalisasi) merupakan ranah kewenangan negara dalam diri pembentuk undang-undang. Sesuai asas negara hukum, maka tindakan negara dalam melakukan kriminalisasi memiliki batasan-batasan agar tindakan tersebut tidak sewenangwenang dan merugikan warga negara. Pernyataan ini dapat dikaitkan dengan konsep negara hukum sebagaimana dijelaskan oleh Brian Z. Tamanaha. Menurut Tamanaha, secara konseptual the Rule of Law atau negara hukum memiliki "to impose legal restraints on government officials." Fungsi ini dilakukan dengan dua cara. Pertama, government officials must abide by valid positive laws in force at the time of any given action. Konsekuensi yang kemudian timbul: "government actions must have positive legal authorization (without which the action is improper); and no government action may contravene a legal prohibition or restriction." ${ }^{3}$

Tetapi meskipun negara yang membuat peraturan perundangundangan, tidak berarti negara tidak terikat olehnya. Cara kedua, "imposes restrictions on the law itself, erecting limitations on the law making power of the government." ${ }^{4}$ Konsekuensinya ialah:

certain prohibited actions cannot be legally allowed, even by a legitimate lawmaking authority. Legal restrictions of this sort rank above (control over) ordinary law-making. The most familiar versions of this are: 1) constitutionally imposed limits, 2) transnational or international legal limits, 3) human rights limits, and 4) religious or natural law limits. In different ways and senses, these types of law are superior to and impose restraints upon routine law making. ${ }^{5}$

Persak yang concern dengan isu pembatasan dalam kriminalisasi berpendapat tentang hubungan antara kriminalisasi dan asas negara hukum sebagai berikut:

The enactment of the criminal legislation is from the individual's standpoint one of the most intrusive and repressive acts of State power, for it not only restricts his freedom of action but also punishes

Nina Persak, Criminalising Harmful Conduct: The Harm Principle, Its Limits and Continental Counterparts (Springer 2007) 6.

3 Brian Z. Tamanaha, 'A Concise Guide of the Rule of Law' dalam Gianluigi Palombella dan Neil Walker, eds., Relocating the Rule of Law (Hart Publishing 2009) 4.

Ibid. 4-5.

Ibid. 5. 
infringements (often with deprivation of the individual's liberty). In today's liberal demo-cratic societies, governed by the rule of law, it is presumed that the everyday communication between the individual and the State follows certain prearranged rules of fair play and that the State does not (and should not) have a completely free hand in proscribing conduct of its citizens. Apart from the system of checks and balances (the separation of powers), the concept of 'civil society' and the requirement of governmental transparency, which are all types of limitations on the State, the restriction of the State's power in the sphere of criminalisation should involve requiring legitimate or justifiable reasons, principles for criminalisation. ${ }^{6}$

Dalam pendapat tersebut Persak memberikan satu penekanan penting bahwa tindakan kriminalisasi harus didasari oleh legitimate or justifiable reasons yang disebut dengan istilah principles for criminalisation. Berdasarkan pendapat tersebut, principles for criminalisation bertumpu pada konsep pembatasan terhadap kekuasaan negara/pemerintah dengan bertolak dari gagasan otonomi atau kebebasan individu.

Ketika menyatakan pendapatnya, Persak membatasi wilayah keberlakuan pendapat tersebut dengan konsep kenegaraan tertentu yang disebut liberal democratic societies. Artinya, secara a contrario, pendapat ini akan tidak berlaku pada negara yang bukan liberal democratic societies. Sebelum melangkah lebih lanjut maka penulis akan membahas terlebih dahulu keberlakuan argumen di atas bagi Indonesia dengan pertanyaan: Apakah Indonesia memenuhi kriteria liberal democratic societies di mana argumen principles for criminalisation ini juga berlaku?

Persak memaknai konsep liberal democratic societies secara longgar dengan tolok ukur berlakunya gagasan tentang individual liberty yaitu: "that the State should operate according to principles of Rechtstaatlichkeit that emphasise indivi-dual liberty." " Dengan kriteria ini maka semua negara yang dapat dibuktikan telah mengakui keberlakuan kaidah-kaidah HAM universal dapat dikatagorikan sebagai liberal democratic societies termasuk Indonesia yang telah memberikan jaminan keberlakuan HAM secara yuridis melalui Bab XA Undang-Undang Dasar Negara Republik Indonesia Tahun 1945 dan Undang-Undang Republik Indonesia Nomor 39 Tahun 1999 tentang Hak Asasi Manusia. Berdasarkan penilaian ini maka pendapat Persak tentang hubungan antara kriminalisasi dengan asas negara hukum dapat dinyatakan berlaku bagi Indonesia karena Indonesia merupakan liberal democratic societies. Dengan demikian berlaku pula argumen Persak tentang principles for criminalisation bagi Indonesia.

Pengertian principles for criminalisation sebagai dasar bagi tindakan kriminalisasi oleh negara seperti yang dikehendaki Persak adalah: "liberal in the sense that it is committed to 
the individual's liberty and supports a minimalist approach to criminalisation." Persak menjustifikasi argumennya sebagai berikut: "As the criminal law is the most intrusive of the institutions of formal social control, with lasting and sweeping implications for the individual, it should be, therefore, kept to the minimum. The individual's life and values take priority over the community's or the State's interests." 9 Pendapat Persak di atas berlaku sebagai argumen bagi penulis dalam mengkritisi isu kriminalisasi di Indonesia, khususnya dalam kasus tindak pidana korupsi pada pengadaan barang/jasa pemerintah secara umum dan pengadaan jasa konstruksi pemerintah secara khusus. Pendapat Persak tentang kriminalisasi pada hakikatnya diprioritaskan pada fungsi hukum pidana yang minimal, serta pengutamaan kehidupan dan nilainilai individual ketimbang kepentingan negara atau masyarakat. Argumen untuk sampai pada pendirian tersebut adalah karena Hukum Pidana sebagai instrumen kontrol sosial bersifat paling intrusif ke dalam kehidupan pribadi atau individu.

Isu tentang pembatasan terhadap kekuasaan pembentuk undang-undang dalam melakukan kriminalisasi didiskusikan secara menarik oleh Dennis J. Baker yang secara spesifik mengajukan argumen penolakan terhadap kriminalisasi dengan tesis hak, yaitu the right not to be unfairly criminalized. Dengan tesis hak tidak berarti bahwa Baker menolak suatu tindakan dikriminalisasi sama sekali, tetapi yang ditolaknya ialah unprincipled criminalization atau unfair criminalization. Dalam membangun tesisnya Baker bertolak dari hubungan antara Hukum Tata Negara dan Hukum Pidana. Hukum Tata Negara, dengan hak-hak konstitusional di dalamnya, bersifat membatasi tindakan kriminalisasi oleh pembentuk undangundang yang akan menghasilkan Hukum Pidana materiil. Baker menyatakan tujuan penulisan bukunya sebagai tesis yang akan dipertahankan sebagai berikut: "the moral criteria for constraining unjust criminalization can and have been incorporated into constitutional human rights and thus provide us with a legal right not to be unfairly criminalized. The aim of the book is to set out the constitutional limits of the substantive criminal law." 10

Perhatian utama Baker adalah "ensuring that people are only criminalized when they deserve it." 11 Pemikiran yang mendasarinya ialah: "Criminalization has harmful consequences for those who are labeled as criminals and therefore people have a right not to be criminalized unless it is fair to override their right." 12 Yang dimaksud dengan harmful consequences adalah dikenakannya sanksi pidana yang

Ibid. 1.

Ibid.

10 Dennis J. Baker, The Right Not to be Criminalized: Demarcating Criminal Law's Authority (Ashgate 2011) 1 .

$11 \quad$ Ibid. 2.

12 Ibid. 
bersifat memberi nestapa kepada diri terpidana, sehingga menentukan suatu tindakan sebagai tindak pidana harus didasari justifikasi yang mampu mengesampingkan hak untuk tidak dikriminalisasi tersebut. Pemikiran ini di-back up argumen: "The right to not to be criminalized is a basic human right that aims to protect individuals from unwarranted State interference of a penal nature." ${ }^{13}$ Baker mencontohkan bentukbentuk praktik unjust and unfair criminalization sebagai berikut:

the mislabeling of innocuous conduct as criminal; eliminating the ex post culpability requirement without moral justification (strict and vicarious liability for crimes that result in a conviction and/ or imprisonment); eliminating the ex ante 'imputability of blame for remote harm' requirement without justification (i.e., criminalizing people for being a mere 'but for' cause of harm caused by the intervening choices of others: remote harms); imposing disproportional punishments; and through the circumvention of human rights and due process protections by, for example, blurring the civil and criminal law. ${ }^{14}$

Poin terakhir pendapat Baker, yaitu "the circumvention of human rights and due process protections by, for example, blurring the civil and criminal law" akan menjadi perhatian utama penulis ketika mengkritisi kriminalisasi korupsi di Indonesia (UU Tipikor dan hubungannya dengan undang-undang yang lain seperti tentang kontrak dan HAM), khususnya pada tataran penerapannya oleh aparat hukum (penyidikan sampai dengan putusan pengadilan) pada kasus-kasus kontrak pengadaan pemerintah (barang, jasa dan jasa konstruksi).

\section{Kriminalisasi yang Legitimate versus Kriminalisasi Berlebih}

Sebagaimana dijelaskan di atas, keputusan pembentuk undang-undang untuk melakukan kriminalisasi tunduk pada pembatasan substansial, tidak hanya pembatasan formal (yaitu hanya dapat dilakukan oleh pembentuk undang-undang berwenang secara konstitusional melalui undang-undang). Pada sub-judul ini penulis akan mempertajam pengertian di atas dengan mengana-lisis lebih lanjut mengenai implikasi dari produk kriminalisasi pembentuk undang-undang jika dikaitkan dengan pembatasan substansial yang ada dalam melakukan tindakan kriminalisasi tersebut.

Andrew Ashworth berpendapat bahwa faktor penentu dalam keputusan melakukan kriminalisasi adalah "political opportunism and power, both linked to the prevailing political culture of the country." 15 Pendapat ini bukan tanggapan yang bermakna positif, tetapi kritik terhadap praktik yang berjalan. Pandangan tradisional dalam kriminalisasi berpedoman pada dua pertanyaan: (1) is the conduct harmful to individuals or to society?; dan (2) is the conduct immoral? Jika dua pertanyaan ini dijawab positif maka secara prinsip tindakan tersebut layak dikriminalisasi. ${ }^{16}$ Pendapat demikian

\section{Ibid. 9.}

Ibid.

Denis Lanser, et.al., Principles of Criminal Law (Cavendish Publishing 2000) 12.

Ibid. 
sudah tidak berlaku pada saat sekarang ini karena terlalu simplistik. Denis Lanser et.al. mengemukakan: "some acts are both immoral and harmful and yet have not been criminalised (for example, adultery), whilst others are neither immoral nor harmful and yet are crimes (for example, failure to wear a seat belt and some other 'victimless' crimes)." ${ }^{17}$

Selanjutnya Lanser et.al. mengemukakan alasan mengapa tidak setiap tindakan immoral saat ini tidak dikriminalisasi:

1. Difficulties of proof (many such acts occur in private and in the absence of independent witnesses);

2. Difficulties of definition (take the example of the husband whose wife deserted him many years ago and who has now found a new partner. If he engages in sexual intercourse, do we really wish to see him punished as an 'adulterer'?);

3. Rules of morality are sometimes difficult to enforce without infringing the individual's right to privacy;

4. The civil law sometimes provides an adequate remedy to the parties affected by the conduct (for example, the deserted wife);

5. In any event, how do we ascertain prevailing 'moral opinion' given the deep divisions within modern society ${ }^{18}$

Kriminalisasi pada hakikatnya adalah isu sangat kompleks.
Kriminalisasi dengan pengertian sebagai pembuatan undang-undang pidana adalah penerapan kekuasaan negara dalam bentuk tindakan paling represif dan bersifat gangguan terhadap kebebasan (HAM) setiap individu. Sikap kritis terhadap hukum pidana dan kriminalisasi secara umum nampak dari pernyataan tidak langsung Herbert L. Packer berikut ini: "The criminal sanction is at once prime guarantor and prime threatener of human freedom. Used providently and humanely it is guarantor; used indiscriminately and coercively, it is threatener."19 Pendapat Packer pada hakikatnya tidak terkait langsung dengan isu kriminalisasi, tetapi pada fase penerapan Hukum Pidana materiilnya. Namun demikian, apa yang menjadi kritisisme tersebut tidak akan terjadi jika tidak didahului sebelumnya dengan proses kriminalisasi.

Pada kesempatan lain Ashworth berpendapat bahwa, dengan bertolak dari pemikiran Sanford H. Kadish, kriminalisasi dan hukum pidana bukan satu-satunya instrumen dalam rangka mengatur perilaku subjek hukum. Tesis Ashworth tentang kriminalisasi berlebih adalah terlampauinya fungsi yang legitimate dari Hukum Pidana karena pembentuk undang-undang mengabaikan perbedaan antara criminal law dan regulatory laws. Ashworth menyatakan:

There is a sense that the criminal law is not simply one of a range of techniques

\section{Ibid. 12-13.}

Ibid. 13.

19 Herbert L. Packer, The Limits of the Criminal Sanction (Stanford University Press 1968) 366. 
available to the legislature for regulating the conduct and activities of subjects. A wide range of regulatory regimes now offer themselves, from licensing to franchising, from financial regulation to environmental standards and so forth. Most modern democracies include a number of statutory regulatory bodies, charged with the task of regulating particular activities. The civil law also regulates conduct in many ways, although it typically leaves it to the aggrieved party to initiate enforcement measures. ${ }^{20}$

Pendapat Ashworth ini menarik karena mengaitkan kriminalisasi (Hukum Pidana) dengan bidang-bidang hukum lain yang pada hakikatnya memiliki sifat atau karakter yang sama yaitu untuk mengatur tindakan subjek hukum. Dikaitkan dengan keberlakuan bidang-bidang hukum lainnya sebagai instrumen bagi negara dalam melakukan pengaturan maka pendapat Ashworth ini dapat bermakna bahwa kriminalisasi suatu tindakan adalah ultimum remedium. Jika sebaliknya, maka kriminalisasi tersebut patut diberikan penilaian sebagai upaya kriminalisasi berlebih.

Sarjana yang secara spesifik menggunakan konsep kriminalisasi berlebih sebagai kriminalisasi yang tidak legitimate adalah Douglas Husak. Konsep kriminalisasi berlebih digunakan Husak untuk menggambarkan fenomena terlalu banyaknya ancaman pidana yang dibuat oleh negara terhadap warganya. ${ }^{21}$ Target Husak adalah menghasilkan teori kriminalisasi, yaitu "a normative framework to distinguish those criminal laws that are justified from those that are not." 22 Pendapat Husak pada hakikatnya merupakan tanggapan atas fenomena di Amerika Serikat yang menurutnya: "We overpunish and overcriminalize." ${ }^{23}$ Sudut pandang dari teori Husak adalah kriminalisasi dan Hukum Pidana merupakan ultimum remedium. Karena itu ada batas-batas bagi dapat tidaknya suatu tindakan dikriminalisasi, sehingga pada akhirnya apakah tindakan itu memang layak menjadi objek dari Hukum Pidana atau tidak.

Pendapat sarjana Indonesia yang otoritatif tentang kriminalisasi adalah Moeljatno yang menanggapi persoalan ini dari dua sisi yaitu pemerintah dan masyarakat. Moeljatno menyatakan: "Adapun ukurannya, perbuatan melawan hukum yang mana yang ditentukan sebagai perbuatan pidana, hal itu adalah termasuk kebijaksanaan pemerintah, yang dipengaruhi oleh berbagai bagai faktor." ${ }^{24}$ Selanjutnya Moeljatno berpendapat:

Selain daripada kewajiban Pemerintah untuk dengan bijaksana menyesuaikan apa yang ditentukan sebagai perbuatan pidana itu dengan perasaan hukum yang hidup dalam masyarakat, maka penentuan itu juga tergantung pada pandangan, apakah ancaman dan

20 Andrew Ashworth, 'Conceptions of Overcriminalization' Ohio State Criminal Law Journal (2008) 5, 407, 408.

21 Douglas Husak, Overcriminalization: The Limits of the Criminal Law (Oxford University Press 2008) 3 .

22 Ibid.

23 Ibid. 4

24 Moeljatno, Asas-asas Hukum Pidana (Rineka Cipta 1993) 3-4. 
penjatuhan pidana itu adalah jalan yang utama untuk mencegah dilanggarnya larangan-larangan tersebut. ${ }^{25}$

Berdasarkan pendapat di atas nampak bahwa Moeljatno sangat menyadari potensi kesewenangwenangan yang inheren dalam Hukum Pidana itu sendiri serta potensi inefektivitasnya. Dalam komentar yang selanjutnya Moeljatno menyatakan: "Pernah dikatakan orang, bahwa kalau kebanyakan perbuatan melawan hukum dijadikan perbuatan pidana, sehingga tidak sesuai lagi dengan kebutuhan masyarakat menurut perasaan hukum yang hidup di dalamnya, maka akibatnya timbullah inflasi pidana, sehingga penghargaan terhadapnya tidak sebagaimana mestinya lagi." ${ }^{26}$ Pendapat Moeljatno tersebut koheren dengan pendapat akademis terkini mengenai fenomena kriminalisasi berlebih.

Sebagaimana dijelaskan di atas, kriteria diberlakukannya kriminalisasi adalah sifat melawan hukumnya suatu tindakan, yaitu merugikan kepentingan individu lain atau masyarakat. Namun demikian ada pengecualianpengecualian terhadap kriteria tersebut. Moeljatno mengemukakan:

perbuatan tidak menepatijanji (break of trust); juga tidak membayar utang dan sebagainya, walaupun sudah nyata bahwa perbuatan-perbuatan ini bersifat melawan hukum dan merugikan masyarakat. Perbuatan yang disebut belakangan ini tidak dapat dituntut menurut hukum pidana, tapi pihak yang dirugikan dapat menuntut penggantian menurut hukum perdata. ${ }^{27}$

Ibid. 4.

Ibid.

Ibid. 3.

R.A. Duff, Answering for Crime: Responsibility and Liability in Criminal Law (Hart Publishing 2007) 91.
Pendapat Moeljatno tersebut relevan dengan pembahasan ini. Artinya, jika dikaitkan dengan bidang-bidang hukum lain, kriminalisasi tidak mutlak untuk dilakukan.

Termasuk pertanggungjawaban pidana, yaitu jika pada momen yang sama tindakan tersebut merupakan tindak pidana dan secara bersamaan merupakan pelanggaran terhadap bidang hukum yang lain. Contoh kasus di atas adalah pelanggaran terhadap kontrak yang berlaku (wanprestasi), sehingga meskipun esensinya tindakan tersebut bersifat melawan hukum, tetapi tindakan tersebut tidak dapat dituntut berdasarkan Hukum Pidana, karena mampu diselesaikan secara kontraktual.

Menyangkut pilihan melakukan kriminalisasi ini pendapat sarjana yang juga otoritatif adalah R.A. Duff yang menyatakan tolok ukur atau parameter bagi pembentuk undang-undang ketika akan melakukan kriminalisasi:

First, the legislature must decide whether to regulate this type of conduct: does it have good reason, relating to the common good of the community, to regulate what was until now unregulated? If it decides to regulate, a second question then arises: how, if at all, should the regulation be enforced? Should there be a formal enforcement mechanism at all, or should citizens just be exhorted to obey? If it is to be formally enforced, should it be enforced as an 'administrative' regulation breaches of which attract penalties but not punishments; or should it be given the force of criminal law, so that breaches of it attract conviction and punishment lat a level appropriate to the non-serious character of the offence)? ${ }^{28}$ 
Dua pertanyaan tersebut merupakan pertanyaan yang harus dipertimbangkan secara matang oleh pembentuk undang-undang sebelum tiba pada keputusan untuk melakukan kriminalisasi. Dengan menyimak dua pertanyaan tersebut maka pada hakikatnya kriminalisasi bukan satusatunya pengaturan oleh pembentuk undang-undang sebagai dasar dalam rangka kontrol sosial. Pengaturan yang bersifat hukum administrasi atau keperdataan sekalipun fungsinya juga sama dalam konteks kontrol sosial tanpa harus menjadikan pengaturan tersebut sebagai pengaturan Hukum Pidana.

Isu utama yang dihadapi saat ini adalah miskonsepsi bahwa hukum yang sebenarnya adalah hukum yang mengandung ancaman pidana. Jika suatu kaidah atau ketentuan tidak mengandung ancaman sanksi pidana maka kaidah atau ketentuan tersebut tidak dianggap sebagai hukum. Oleh karena itu tidak mengherankan jika keputusan untuk melakukan kriminalisasi suatu tindakan dewasa ini menjadi sangat mudah. Menurut hemat penulis, dengan melihat teori-teori yang telah dikemukakan di atas sebagai bentuk reaksi terhadap fenomena kriminalisasi yang berlebihan, pembatasan terhadap kriminalisasi dan Hukum Pidana seyogianya dilihat menurut esensi dari Hukum Pidana yang menurut sifatnya sering diibaratkan dengan pedang bermata dua, melindungi kepentingan umum dengan sekaligus melukai diri si terpidana. Oleh karena itu, setelah mempertimbangkan uraian di atas, yang penting dalam memikirkan pembatasan terhadap kriminalisasi adalah fungsi bidang-bidang hukum lain sehingga, supaya tidak terjadi kriminalisasi berlebih, jika bidang-bidang hukum tersebut fungsional maka sudah selayaknya jika kriminalisasi ditempatkan sebagai upaya terakhir setelah bidang-bidang hukum tersebut tidak mampu menyelesaikan masalah yang dihadapi.

\section{Kriminalisasi Berlebih dalam Pasal 2 ayat (1) dan Pasal 3 UU Tipikor}

R.A. Duff mengemukakan argumen tentang kriminalisasi yang legitimate sebagai berikut: "we should criminalise wrongful conduct because it is wrongful." ${ }^{29}$ Pendapat Duff tentang layaknya suatu tindakan dikriminalisasi bertumpu pada sifat tercelanya tindakan. Argumen ini sangat penting karena membedakan karakter penghukuman melalui Hukum Pidana dengan bidang hukum lain: "Criminal convictions and punishments do not merely penalise; they condemn." 30 Pada poin ini sebenarnya sangat mudah untuk menyepakati bahwa korupsi merupakan tindakan tercela yang patut dikriminalisasi. Tetapi isunya tidak demikian. Perhatian penulis di sini tertuju pada kriminalisasi korupsi oleh Pasal 2 ayat (1) dan Pasal 3 UU Tipikor yang telah 'memakan' banyak korban dalam kontrak-kontrak pemerintah 
(government contract) untuk pengadaan barang dan jasa pemerintah.

Pasal 2 ayat (1) dan Pasal 3 UU Tipikor berpeluang menjadikan hubungan kontraktual dengan pemerintah menjadi objek sanksi pidana (tindak pidana korupsi) manakala terjadi kerugian terhadap keuangan negara. Sementara, potensi terjadinya kerugian terhadap keuangan negara dalam situasi yang demikian sangat besar. Oleh karena itu, dalam kasus demikian, penjatuhan sanksi pidana berdasarkan Pasal 2 ayat (1) dan Pasal 3 UU Tipikor tidak seyogianya dilakukan (terutama terkait kerugian dalam pelaksanaan kontrak kerja konstruksi dengan pemerintah yang akan dijelaskan lebih lanjut di bawah).

Mengkualifisir tindak pidana dalam fase pelaksanaan kontrak pemerintah di bidang pengadaan barang dan jasa pada hakikatnya tidak dapat penulis setujui karena, sebagai asas umum, hal itu murni merupakan ranah keperdataan manakala prosedur pengadaannya wajar, begitu pula klausul-klausul kontraknya. Kondisi khusus sebagai pengecualiannya adalah jika dalam pelaksanaan kontrak ada kesengajaan itikad buruk dari pihak penyedia barang atau jasa dengan tidak menunaikan prestasinya, di mana jika hal itu dilakukan akan berakibat kerugian terhadap keuangan negara. Di sini kata kuncinya untuk kemungkinan penerapan tindak pidana adalah pembuktian kesengajaan itikad buruk untuk tidak menunaikan prestasi (kursif - penulis). Dalam kondisi demikian maka hak untuk memperoleh penyelesaian secara kontraktual dan bebas dari ancaman pidana tidak berlaku lagi atau dikesampingkan.

Dalam kasus ini kaidah hukum yang hendak dipertahankan adalah: Pelaksanaan kontrak pemerintah yang sah oleh para pihak dengan itikad baik harus diberikan jaminan berupa kebebasan dari ancaman pidana (dalam hal ini tindak pidana korupsi). Pihak yang beritikad baik dalam menjalankan kontrak pemerintah dapat membuat alasan penga-yaan diri berdasarkan kontrak untuk membela diri dari ancaman tindak pidana korupsi. Dengan demikian pilihan atas upaya penyelesaian kontraktual dapat dipertahankan. Keuangan negara pun dapat dijamin keamanannya dalam pelaksanaan kontrak pemerintah karena kerugian terhadap keuangan negara yang mungkin timbul dapat dipulihkan melalui upaya penyelesaian kontraktual (tanpa perlu memenuhi penjara dengan orang-orang berpredikat koruptor karena merugikan keuangan negara dalam pelaksanaan kontrak pemerintah).

Penggunaan upaya pidana dalam kasus ini (UU Tipikor) adalah berlebihan atau tidak proporsional. Hal ini dapat menjadi disinsentif bagi iklim bisnis di Indonesia karena dapat men-discourage niat seseorang untuk menjadi penyedia barang atau jasa bagi pemerintah. Namun harapan demikian sangat sulit direalisir karena kelemahan dalam kriminalisasi korupsi oleh Pasal 2 ayat (1) dan Pasal 3 UU Tipikor yang penulis 
kualifikasikan sebagai kriminalisasi berlebih.

Dalam pembentukan UU Tipikor nampak bahwa politik hukum pembentuk undang-undang adalah meningkatkan efektivitas legislasi dalam rangka pemberantasan tindak pidana korupsi yang ditempuh dengan jalan mengganti UU No. 3 Tahun 1971 dengan UU No. 31 Tahun 1999. Peningkatan efektivitas legislasi dilakukan dengan cara:

... Undang-undang ini memuat ketentuan pidana yang berbeda dengan Undang-undang sebelumnya, yaitu menentukan ancaman pidana minimum khusus, pidana denda yang lebih tinggi, dan ancaman pidana mati yang merupakan pemberatan pidana. Selain itu, Undang-undang ini memuat juga pidana penjara bagi pelaku tindak pidana korupsi yang tidak dapat membayar pidana tambahan berupa uang pengganti kerugian negara. ${ }^{31}$

Kutipan di atas menunjukkan bahwa kriminalisasi tindakan korupsi oleh UU Tipikor secara inheren mengandung karakter eksesif. Indikasi ini semakin menonjol dalam perubahan UU No. 31 Tahun 1999 yang menyatakan bahwa politik hukum untuk perubahan ialah: "mengingat korupsi di Indonesia terjadi secara sistematik dan meluas sehingga tidak hanya merugikan keuangan negara, tetapi juga telah melanggar hak-hak sosial dan ekonomi masyarakat secara luas, maka pemberantasan korupsi perlu dilakukan dengan cara luar biasa (penekanan penulis)." 32

\footnotetext{
$\begin{array}{ll}31 & \text { Ibid. } \\ 32 & \text { Penjelasan Umum UU No. } 20 \text { Tahun } 2001 .\end{array}$

$\begin{array}{ll}31 & \text { Ibid. } \\ 32 & \text { Penjelasan Umum UU No. } 20 \text { Tahun } 2001 .\end{array}$
}

Sepintas politik hukum tersebut nampak rasional mengingat dampak dari korupsi sangat luar biasa pada berbagai bidang kehidupan sehingga wajar jika reaksi yang diberikan juga harus tegas dan keras. Akan tetapi justru di sini masalahnya. Dengan skema pengaturan yang secara lahir berkarakter eksesif maka penerapannya potensial bermasalah. Sebagai peringatan serius untuk eksistensi UU Tipikor ini, perdebatan tentang arah politik hukumnya terekam secara eksplisit dalam Putusan Mahkamah Konstitusi Republik Indonesia Nomor 003/PUU-IV/2006. Isu utama kasus ini adalah tentang keberlakuan sifat melawan hukum materiil dalam fungsinya yang positif serta keberlakuan tindak pidana korupsi sebagai delik formil dalam Pasal 2 ayat (1) dan Pasal 3 UU No. 31 Tahun 1999 dikaitkan dengan hakikat Hukum Pidana sebagai lex certa dalam kerangka asas legalitas.

Andi Hamzah, saksi ahli dalam kasus ini tidak sependapat dengan logika berpikir DPR yang menyatakan bahwa keberlakuan delik formil itu bersifat untuk mencegah kerugian potensial. Hamzah berargumen bahwa kerugian harus konkret karena secara sistematis berkaitan dengan unsur memperkaya diri sendiri atau orang lain:

Bahwa melawan hukum berkaitan dengan frase di bawahnya yaitu melawan hukum memperkaya diri sendiri, dan memperkaya dimaksud dilakukan dengan melawan hukum. Kata melawan hukum dan memperkaya tidak lepas satu sama lain, namun 
melawan hukum dilakukan untuk memperkaya diri sendiri atau orang lain atau suatu korporasi.

Bahwa Ahli dapat menerima, kata "dapat" dengan penafsiran harus menggunakan ahli. Karena tidak dapat hanya dengan mengatakan "potensial dapat merugikan negara”.

Bahwa Ahli dapat menerima kata dapat asalkan dalam proses pembuktian masing-masing pihak dapat mengajukan akuntan, apabila Hakim masih ragu-ragu atas keterangan akuntan yang diajukan oleh masingmasing pihak, maka hakim harus memutus bebas (in dubio proreo).

Bahwa Ahli tidak mempermasalahkan kata "dapat", tetapi Ahli berpendapat menjadi mubazir karena memperkaya diri sendiri harus dibuktikan, harus konkret. Kata "dapat" harus berada di bawah memperkaya, bukan di atasnya. ${ }^{33}$

Eman Radjagukguk, saksi ahli pada kasus yang sama, juga tidak sepakat dengan DPR atas keberlakuan Pasal 2 ayat (1) UU No. 31 Tahun 1999 sebagai delik formil. Radjagukguk mengemukakan dua argumen untuk menolak status Pasal 2 ayat (1) UU No. 31 Tahun 1999 sebagai delik formil:

a. Kata-kata “... yang dapat merugikan keuangan negara atau perekonomian negara ...", yang dapat ditafsirkan menurut kehendak siapa saja yang membacanya tidak mendatangkan kepastian hukum kepada pencari keadilan dan Penegak Hukum, karena perbuatan atau peristiwa tersebut belum nyata atau belum tentu terjadi dan belum pasti jumlahnya;

b. Telah ada definisi "kerugian negara" yang menciptakan kepastian hukum, yaitu sebagaimana yang tercantum dalam Undang-undang
Nomor 1 Tahun 2004 tentang Perbendaharaan Negara, Pasal 1 ayat (22): "Kerugian negara/daerah adalah kekurangan uang, surat berharga, dan barang, yang nyata dan pasti jumlahnya sebagai akibat perbuatan melawan hukum baik sengaja maupun lalai" (garis bawah dari Ahli). "Kerugian negara yang nyata dan pasti jumlahnya...", memberi kepastian hukum. ${ }^{34}$

Mahkamah Konstitusi dalam kasus ini dapat menerima politik hukum pembentuk undang-undang yang secara teleologis memaknai bahwa pemberlakuan delik formil tersebut bersifat deteren dan berfungsi preventif, yaitu menghindari kerugian potensial pada negara. ${ }^{35}$ Namun, praktik penerapan ketentuan ini masih mungkin menimbulkan ketidakpastian hukum. Oleh karena itu, untuk mengantisipasinya, Mahkamah Konstitusi memberikan interpretasi sebagai pedoman bagi aparat penegak hukum yang akan menerapkan ketentuan tersebut sebagai berikut:

Menimbang bahwa dengan ada-nya penjelasan yang menyatakan bahwa kata "dapat" sebelum frasa "merugikan keuangan negara atau perekonomian negara", kemudian mengkualifikasikannya sebagai delik formil, sehingga adanya kerugian negara atau perekonomian negara tidak merupakan akibat yang harus nyata terjadi, Mahkamah berpendapat bahwa hal demikian ditafsirkan bahwa unsur kerugian negara harus dibuktikan dan harus dapat dihitung, meskipun sebagai perkiraan atau meskipun belum terjadi. Kesimpulan demikian harus ditentukan oleh seorang ahli di bidangnya. ${ }^{36}$

\footnotetext{
33 Putusan Mahkamah Konstitusi Republik Indonesia No. 003/PUU-IV/2006, Mahkamah Konstitusi, 25 Juli 2006. 60-61.

$34 \quad$ Ibid., 57.

35 Ibid., 65-72.

$36 \quad$ Ibid., 72.
} 
Selanjutnya perdebatan tentang validitas keberlakuan sifat melawan hukum materiil dalam fungsinya yang positif. Menjelaskan tentang keberlakuan sifat melawan hukum materiil dalam fungsinya yang positif DPR menyatakan:

Suatu perbuatan yang tidak diatur atau tidak melanggar peraturan perundangundangan tapi karena perbuatan itu tercela maka kata "dapat" disini merupakan penjelasan dari pembentuk undang-undang kepada para pelaksana undang-undang dalam hal ini polisi dan jaksa. Dalam praktek sering kali unsurunsur melawan hukum dari cara-cara perbuatan korupsi yang sangat tercela dimasukkan kedalam unsur melawan hukum ... Hal ini yang dimaksud oleh penjelasan pembuat undang-undang untuk memberikan pandangan yang lebih luas dari apa yang ditulis pada Pasal 2 mengenai apa yang dimaksud dengan melawan hukum tapi juga bagi penegak hukum untuk memperluas arti penafsiran melawan hukum yang tidak hanya terbatas pada melanggar hukum tertulis tapi juga melanggar rasa keadilan masyarakat. ${ }^{37}$

Andi Hamzah menanggapi pendapat DPR tentang validitas keberlakuan sifat melawan hukum materiil dengan menyimpulkan bahwa Pasal 2 dan 3 UU No. 31 Tahun 1999 adalah bentuk analogi yang bertentangan dengan asas legalitas:

Bahwa melawan hukum yang dalam penjelasan pasal-pasal UU a quo bukan saja bertentangan dengan perundangundangan tetapi juga bertentangan dengan norma-norma lain yang hidup di dalam masyarakat adalah merupakan penyimpangan dengan asas legalitas. Asas legalitas mengatakan bahwa tidak seorangpun dapat dipidana selain berdasarkan ketentuan perundangundangan pidana yang ada sebelumnya. Asas legalitas artinya tiga:

1. Undang-undang peraturan itu harus tertulis, sudah disebutkan tadi lex scripta;

2. Undang-undang tidak boleh berlaku surut;

3. Dilarang analogi, baik analogi undang-undang maupun analogi hukum.

Bahwa recht analogi sama sekali tidak ada di dalam undang-undang, hanya bertentangan, kepatutan di dalam masyarakat itu namanya recht analogie. Negara yang menganut recht analogie adalah Jerman (Nazi), zaman Hitler dengan KUHP-nya tahun 1936. Tidak ada negara menganut recht analogie, tidak ada tertulis, tetapi masyarakat perlu dipidana, maka dipidana.

Bahwa Pasal 2 UU a quo adalah recht analogie, artinya suatu perbuatan tidak ada di dalam undang-undang tetapi bertentangan dengan kepatutan, kelaziman, norma-norma yang hidup dalam masyarakat. ${ }^{38}$

Poin penting pendapat Hamzah adalah bahaya yang potensial ditimbulkan oleh Hukum Pidana yang tidak didasarkan pada undang-undang yang berlaku prospektif sesuai asas legalitas. Bahaya tersebut adalah tanpa adanya undangundang pidana, jika negara memandang bahwa masyarakat perlu dipidana, maka dia akan dipidana. Dengan pengertian lain, pendapat ini sejalan dengan teori batas-batas kriminalisasi yang menghendaki agar kriminalisasi sungguh-sungguh dibatasi, dan level pertama pembatasannya adalah dengan kewajiban negara memberlakukan undang-undang dalam mengkriminalisasi suatu tindakan. 
Dalam kasus ini, penerapan sifat melawan hukum materiil dalam fungsinya yang positif jelas bertentangan dengan prinsip kriminalisasi yang legitimate karena menghasilkan Hukum Pidana materiil (yaitu Pasal 2 ayat [1] dan Pasal 3 UU No. 31 Tahun 1999) yang tidak jelas batas dan ruang lingkup keberlakuannya karena pembentuk undang-undang gagal dalam memenuhi tuntutan asas legalitas. Mahkamah Konstitusi pada akhirnya membatalkan Penjelasan Pasal 2 ayat (1) UU No. 31 Tahun 1999 sepanjang menyangkut penggunaan konsep sifat melawan hukum materiil karena bertentangan dengan kepastian hukum (asas legalitas) serta telah menciptakan kaidah hukum baru yang bukan termasuk ranah Penjelasan. ${ }^{39}$

Berdasarkan uraian di atas penulis berpendapat bahwa politik hukum yang melandasi UU Tipikor masih kontroversial, meskipun satu isu telah diputuskan oleh Mahkamah Konstitusi yaitu inkonstitusionalitas keberlakuan sifat melawan hukum materiil dalam fungsinya yang positif. Lebih lanjut penulis berpendapat, secara akademis, kritisisme terhadap UU Tipikor, dalam hal ini politik hukum serta penjabaran materi muatannya, masih tetap valid sepanjang didukung oleh pendapat atau teori yang dapat dipertanggungjawabkan. Pada poin ini penulis tetap meyakini bahwa UU Tipikor problematis jika dikaji secara objektif berdasarkan teori batas-batas kriminalisasi karena sejak awal politik hukum bahwa tindak pidana korupsi adalah extra-ordinary crime sehingga pemberantasannya harus dengan extraordinary measures bertentangan dengan hakikat dari Hukum Pidana itu sendiri (baik materiil maupun formil) yang ekstra dibatasi karena potensial merampas HAM dan kebebasan warga negara.

Dalam kaitan dengan itu dissenting opinion oleh Hakim Konstitusi Laica Marzuki sangat penting untuk dipertimbangkan kembali sebagai kontekstualisasi teori batas-batas kriminalisasi, khususnya menyangkut keberlakuan delik formil:

Dalam pada itu, pencantuman kata "dapat" pada frasa "yang dapat merugikan keuangan negara atau perekonomian negara" dalam Pasal 2 ayat (1) dan Pasal 3 UU PTPK mengandung cakupan makna (begrippen) yang kurang jelas serta agak luas, tidak memenuhi rumusan kalimat yang in casu disyaratkan bagi asas legalitas suatu ketentuan pidana, yaitu lex certa, artinya ketentuan tersebut harus jelas dan tidak membingungkan (memuat kepastian) serta lex stricta, artinya ketentuan itu harus ditafsirkan secara sempit, tidak boleh dilakukan analogi, sesuai keterangan Ahli Prof. Dr. Romli Atmasasmita, S.H., LL.M. di depan sidang. Kata "dapat" mengoyakngoyak tirai asas Nullum Delictum Nulla Poena Sine Praevia Lege Poenali (Pasal 1 ayat 1 KUHPidana) yang merangkumi semua ketentuan hukum pidana, in casu ketentuan pemberantasan tindak pidana korupsi. Hal dimaksud mengakibatkan ketidakpastian hukum (rechtsonze-kerheid) yang dijamin konstitusi, dalam Pasal 28D ayat (1) UUD 1945.40
$39 \quad$ Ibid., $73-76$.
Ibid., 61. 
Pada bagian ini penulis masih akan melanjutkan analisis sebelumnya mengenai relevansi kriminalisasi terhadap tindakan tertentu menjadi tindak pidana korupsi berdasarkan UU Tipikor. Parameter mengenai relevansi yang akan digunakan di sini bertumpu pada tujuan kriminalisasi dan kebenaran dari tujuan kriminalisasi (legitimate purpose) yang dikehendaki tersebut.

Seperti tersirat dalam UU Tipikor, tujuan kriminalisasi tindakan korupsi adalah penghukuman. Indikasi ini nampak sangat eksplisit dalam penerapan ancaman pidana minimum oleh pembentuk undang-undang sehingga membatasi kebebasan hakim ketika menjatuhkan pidana. Semangat penghukuman ini sangat layak dipertanyakan, terutama terkait pengetahuan umum bahwa korupsi ditengarai merupakan fenomena yang terjadi secara masif. Selain itu, fenomena korupsi juga tidak murni kesalahan individual pelaku, tetapi juga disebabkan oleh faktor sistem. ${ }^{41}$ Oleh karena itu, semangat penghukuman yang digeneralisir sangat tidak tepat, sehingga kriminalisasi tindakan korupsi dapat jatuh pada penilaian tidak legitimate.

Dengan demikian penulis menganggap penting isu pembedaan antara kriminalisasi tindakan korupsi yang legitimate (karena memang diperlukan) dan kriminalisasi tindakan korupsi yang tidak legitimate (karena berlebihan). Dalam konteks demikian penulis akan menganalisis lebih lanjut isu apakah kriminalisasi korupsi yang menghasilkan Pasal 2 ayat (1) UU Tipikor legitimate ataukah tidak.

Problematik tindak pidana korupsi dalam Pasal 2 ayat (1) UU Tipikor adalah penerapannya yang terlalu elastis sehingga sulit menjamin terwujudnya kepastian hukum. Sementara tuntutan kepastian hukum ini sangat diprioritaskan dalam sistem peradilan pidana untuk mencegah seseorang menjadi korban peradilan sesat. Oleh karena itu dalam Hukum Pidana berlaku adagium sangat terkenal terkait dengan kepastian hukum ini yaitu: "lebih baik membebaskan seribu orang yang bersalah daripada menghukum satu orang yang tidak bersalah."

Sifat elastis tersebut karena persinggungan dengan konsep keuangan negara sehingga setiap hubungan hukum antara orang perorangan atau badan hukum swasta dengan pemerintah (dengan melibatkan keuangan negara) sangat potensial menghadapi ancaman tindak pidana korupsi. Salah satu contoh adalah di bidang pengadaan barang dan jasa pemerintah. Memang, merugikan keuangan negara atau perekonomian negara bukan satu-satunya unsur dalam tindak pidana korupsi. Unsur inti (bestanddeel) delik yang sebenarnya dari tindak pidana korupsi Pasal 2 ayat (1) UU Tipikor adalah melawan hukum, sehingga jika unsur melawan hukum

41 Andi Hamzah, Pemberantasan Korupsi melalui Hukum Pidana Nasional dan Internasional (Rajawali Pers 2005) 10-23. 
tidak terbukti maka putusannya adalah lepas dari tuntutan hukum. Jika konsep melawan hukum yang sebenarnya diterapkan secara konsisten dengan asas legalitas maka seharusnya Pasal 2 ayat (1) UU Tipikor ini tidak akan pernah dapat diberlakukan dalam kasus-kasus pengadaan barang dan jasa pemerintah karena Indonesia belum memiliki Undang-Undang Pengadaan Barang dan Jasa Pemerintah. Hal itu sejalan dengan rekomendasi Amiruddin dalam disertasinya yang menyatakan: "Pengaturan pengadaan barang dan jasa oleh pemerintah seyogyanya dalam bentuk undang-undang, sehingga dapat memuat ketentuan pidana. Oleh sebab itu, perlu disusun RUU tentang Pengadaan Barang dan Jasa." ${ }^{42}$ Dengan demikian dapat dikonstruksikan pengertian bahwa sebelum ada Undangundang tentang Pengadaan Barang atau Jasa maka Pasal 2 ayat (1) UU Tipikor tidak dapat diterapkan dalam kasus hubungan kontrak-tual dengan pemerintah dalam rangka pengadaan barang atau jasa. Jika hal itu tetap dilakukan maka merupakan pelanggaran terhadap asas legalitas (Pasal 1 ayat [1] KUHP jo. Pasal 15 UU No. 12 Tahun 2011).

Kembali pada isu aktivasi Pasal 2 ayat (1) UU Tipikor dengan kriminalisasi pelanggaran dalam pengadaan barang atau jasa, menurut penulis hal itu tidak seketika akan menjadikan kualifikasi tindak pidana pengadaan barang atau jasa yang menimbulkan kerugian terhadap keuangan negara sebagai tindak pidana korupsi. Pendapat ini mengacu pada Pasal 14 UU Tipikor yang menentukan: "Setiap orang yang melanggar ketentuan Undang-undang yang secara tegas menyatakan bahwa pelanggaran terhadap ketentuan Undang-undang tersebut sebagai tindak pidana korupsi berlaku ketentuan yang diatur dalam Undang-Undang ini." Pengaturan Pasal 14 UU Tipikor pada hakikatnya merupakan lex specialis untuk mengantisipasi terjadinya situasi suatu perbuatan diancam dengan beberapa ketentuan tindak pidana secara bersamaan. Ratio legis Pasal 14 UU Tipikor adalah sebagai bentuk pembatasan dalam kriminalisasi korupsi supaya tidak terjadi kriminalisasi berlebih. Oleh karena itu, sebagai implikasinya, jika kriminalisasi pelanggaran dalam pengadaan barang atau jasa yang menimbulkan kerugian terhadap keuangan negara tidak dikualifikasi sebagai tindak pidana korupsi oleh pembentuk undangundang maka, sesuai dengan ketentuan Pasal 14, Pasal 2 ayat (1) UU Tipikor tetap tidak dapat diterapkan.

Itu artinya, jika dalam pengadaan barang dan jasa pemerintah dikehendaki supaya ketentuan tindak pidana korupsi Pasal 2 ayat (1) UU Tipikor aplikabel maka pada RUU tentang Pengadaan Barang dan Jasa Pemerintah juga harus dinyatakan secara tegas bahwa pelanggaran undang-undang tersebut adalah tindak pidana korupsi sehingga Pasal 2 ayat (1) UU Tipikor menjadi aplikabel. Sulit dibayangkan apa yang

42 Amiruddin, Korupsi dalam Pengadaan Barang dan Jasa (Genta Publishing 2010) 251. 
akan terjadi jika Pasal 2 ayat (1) UU Tipikor dibaca secara terisolir tanpa dihubungkan dengan Pasal 14-nya: semua kerugian keuangan negara yang dilakukan oleh orang perorangan swasta akan diarahkan sebagai tindak pidana korupsi. Jelas ini adalah inflasi dalam penegakan Hukum Pidana dalam rangka pemberantasan tindak pidana korupsi yang telah memakan banyak korban.

Pada analisis akhir penulis berpendapat bahwa permasalahan hukum di bidang jasa konstruksi adalah isu kontraktual yang tunduk pada ketentuan penyelesaian sengketa berdasarkan kontrak kerja konstruksi, yaitu wanprestasi, meskipun ada unsur kerugian terhadap keuangan negara. Hal ini dapat dilihat dari pengaturan tentang kontrak kerja konstruksi dalam Pasal 22 Undang-Undang Nomor 18 Tahun 1999 tentang Jasa Konstruksi (UU No. 18 Tahun 1999) yang harus memuat salah satunya adalah klausul tentang cidera janji yang mengatur mengenai tanggung jawab dalam hal salah satu pihak tidak melaksanakan kewajiban sebagaimana diperjanjikan.

Pengertian wanprestasi atau cidera janji dalam kasus kontrak kerja konstruksi juga telah ditentukan secara spesifik oleh Pasal 23 Peraturan Pemerintah Nomor 29 Tahun 2000 tentang Penyelenggaraan Jasa Konstruksi (PP No. 29 Tahun 2000) yaitu: (1) tidak menyelesaikan tugas; (2) tidak memenuhi mutu; (3) tidak memenuhi kuantitas; atau (4) tidak menyerahkan hasil pekerjaan. Atas dasar ketentuan tersebut, pemerintah tidak perlu risau menghadapi kemungkinan terjadinya kerugian terhadap keuangan negara dalam pelaksanaan kontrak kerja konstruksi. Hukum, secara kontraktual, sudah memberikan instrumen yang memadai untuk melindungi keuangan negara.

Untuk itu, mengakhiri tanggapan penulis, jika Pasal 2 ayat (1) dan Pasal 3 UU Tipikor tujuannya tidak lain untuk memberikan perlindungan terhadap keuangan negara, maka masih perlukah ancaman sanksi pidana sebagai tindak pidana korupsi manakala secara kontraktual perlindungan terhadap keuangan negara tersebut mampu dilaku-kan dari kerugian yang ditimbulkan orang lain? Inilah mengapa, berdasarkan argumentasi di atas, Pasal 2 ayat (1) dan Pasal 3 UU Tipikor penulis kualifikasikan sebagai kriminalisasi berlebih. Upaya pidana melalui Pasal 2 ayat (1) dan Pasal 3 UU Tipikor terhadap pihak-pihak dalam pelaksanaan kontrak kerja konstruksi yang menimbulkan kerugian terhadap keuangan negara tidak lebih dari upaya menggunakan Hukum Pidana untuk menimbulkan teror. Hal ini bertentangan dengan kodrat dari Hukum Pidana sendiri.

\section{PENUTUP}

Berdasarkan hasil pembahasan di atas maka penulis akan menegaskan kembali beberapa poin argumen yang penting yang sudah dijabarkan:

Pertama, terkait kriminalisasi, keputusan untuk menetapkan suatu tindakan sebagai tindak pidana tidak boleh dijatuhkan sembarangan karena berpotensi melanggar HAM. Kedua, 
kriminalisasi berlebih adalah fenomena kriminalisasi yang tidak legitimate yang harus dihindari supaya keputusan menetapkan suatu tindakan sebagai tindak pidana konsisten dengan tujuan melindungi HAM. Ketiga, Pasal 2 ayat (1) dan Pasal 3 UU Tipikor adalah praktik kriminalisasi berlebih jika dikaitkan dengan pelaksanaan kontrak dalam hubungan kontraktual dengan pemerintah, terutama di bidang jasa konstruksi.

Oleh karena itu, sesuai prinsip yang telah dinyatakan di atas, jika secara kontraktual perlindungan terhadap keuangan negara mampu dilakukan dari kerugian yang ditimbulkan orang lain, maka tidak ada faedahnya menjatuhkan ancaman sanksi pidana kepada orang tersebut (dalam hal ini tindak pidana korupsi). Dalam konteks demikian maka kerugian terhadap keuangan negara dalam pelaksanaan kontrak kerja konstruksi hendaknya dilakukan mengacu pada ketentuan cidera janji/ wanprestasi yang sudah diatur secara jelas oleh peraturan perundangundangan.

\section{DAFTAR BACAAN}

\section{Buku}

Amiruddin, Korupsi dalam Pengadaan Barang dan Jasa (Genta Publishing 2010).

Baker, Dennis J., The Right Not to be Criminalized: Demarcating Criminal Law's Authority (Ashgate 2011).
Duff, R.A., Answering for Crime: Responsibility and Liability in Criminal Law (Hart Publishing 2007).

Hamzah, Andi, Pemberantasan Korupsi melalui Hukum Pidana Nasional dan Internasional (Rajawali Pers 2005).

Husak, Douglas, Overcriminalization: The Limits of the Criminal Law (Oxford University Press 2008).

Moeljatno, Asas-asas Hukum Pidana (Rineka Cipta 1993).

Packer, Herbert L., The Limits of the Criminal Sanction, (Stanford University Press 1968).

Persak, Nina, Criminalising Harmful Conduct: The Harm Principle, Its Limits and Continental Counterparts (Springer 2007).

\section{Jurnal}

Ashworth, Andrew, 'Conceptions of Overcriminalization' (2008) 5 Ohio State Criminal Law Journal 407.

\section{Kontribusi dalam Buku}

Tamanaha, Brian Z., 'A Concise Guide of the Rule of Law' dalam Gianluigi Palombella dan Neil Walker, eds., Relocating the Rule of Law (Hart Publishing 2009. 
